\title{
PSIHOSOCIJALNI ČIMBENICI NA RADNOM MJESTU I ZADOVOLJSTVO RADNIKA U HOTELIJERSTVU
}

UDK 640.4:159.9

PRIMLJENO: 21.1 .2019 .

PRIHVAĆENO: 2.10 .2019

Ovo djelo je dano na korištenje pod Creative

Commons Attribution 4.0 International License

SAŽETAK: Zadovoljstvo na radu je skup pozitivnih ili negativnih osjećaja koje zaposlenici doživljavaju prema svojem poslu, a odnose se na čimbenike kao što su suradnici, sadržaj posla, nadređeni, plaća, uvjeti rada, radno vrijeme, unapređenje, priznanje, status, uspjeh, odgovornost, sigurnost, mogućnost razvoja i dr. U radu je metodom anketnog upitnika zatvorenog tipa provedeno istraživanje o zadovoljstvu na radu između zaposlenika: servir, konobar, pomoćni kuhar i kuhar u jednom hotelu. Anketni upitnik sastoji se od 14 odjeljaka ukupno sa 24 pitanja, pri čemu su obuhvaćena opća pitanja te pitanja koja direktno utječu na zadovoljstvo radnika na radnom mjestu (plaća, radno vrijeme, sigurnost na radu, organiziranost radne organizacije, informiranost $i d r$.). Analizom dobivenih odgovora utvrđeno je da su radnici zadovoljni poduzećem po svim točkama upitnika, pri čemu se postotak zadovoljnih radnika kreće između $77 \%$ i 100 \%, ovisno o pitanju.

Ključne riječi: zadovoljstvo na radu, hotelijerstvo, anketni upitnik

\section{UVOD}

Psihosocijalni čimbenici odnose se na sučeljavanje između zahtjeva posla, poslovnog (radnog) okruženja, sadržaja posla i organizacije posla s jedne strane i radnog učinka, zadovoljstva poslom, radnikovih fizičkih i psihičkih obilježja, znanja, potreba, zadovoljenja kulturnih potreba i navika u odnosu na zahtjeve posla s druge strane (ILO, 1986.). Jednostavno rečeno psihosocijalne čimbenike nazivamo one karakteristike rada koje radnik doživljava nepovoljnim za svoje psihičko, tjelesno i opće zdravlje. U tvrtkama radnici reagiraju različito pri čemu dolazi do većeg nezadovoljstva, opasnosti od povećanog intenziteta stresa na radu, zlostavljanja, izgaranja na poslu, nasilnog ponašanja prema suradnicima ili korisnicima usluge, smanjenja produktivnosti i učinkovitosti.

*Mr. sc. Snježana Kirin, viši predavač, (snjezana.kirin@vuka.hr), Veleučilište u Karlovcu, Odjel Sigurnosti i zaštite, Trg J. J. Strossmayera 9, 47000 Karlovac, Barbara Šimić, struč. ing. sec., studentica Veleučilišta u Karlovcu, Odjel Sigurnosti i zaštite, Trg J. J. Strossmayera 9, 47000 Karlovac.
Cilj svakog suvremenog poduzeća je zadovoljstvo zaposlenika, zadovoljstvo kupaca i proizvodnost s profitom. Zadovoljni zaposlenici čine temelj uspjeha jer upravo su oni jedini nepresušni izvor konkurentne prednosti suvremenih poduzeća, pri čemu je bitno zadovoljstvo na radu, odnos kvalitete, motivacije i predanosti na radu te organizacija rada (Pupovac, Lipovača, Sečen, 2019.).

Zadovoljstvo na radu ovisi o individualnim stavovima zaposlenika o njihovom radu, o tome kako se zaposlenici žele ostvariti na radu, te o tome kako percipiraju određene situacije, odnosno jesu li sretni, zadovoljene i ispunjene njihove potrebe i želje na radu. Čimbenici zadovoljstva na radu mogu biti organizacijski i osobni. Organizacijski čimbenici zadovoljstva na radu proizlaze iz karakteristika samog poduzeća i pojedinačnog radnog mjesta kao što su karakteristike rada (sadržaj i priroda radnih zadataka), mogućnost napredovanja, odnos sa suradnicima, odnos s nadređenima, visina plaće, nagrade i priznanja, uvjeti rada i sigurnost zaposlenja. Osobni čimbenici zadovoljstva na radu su čimbenici na koje 
poduzeće ne može utjecati, već ti čimbenici ovise o samom pojedincu te obuhvaćaju osobne dispozicije, raspoloženje i emocije, usklađenost osobnih interesa i rada, dob, radni staž zaposlenika i status (Noe, Hollenbeck, Gerhart, 2006.). Kad su zaposlenici zadovoljni na radu koji obavljaju, to pozitivno utječe na njihovu produktivnost, što je dobro za poduzeće, ali i za zaposlene i njihovo samopoštovanje i ukupno zadovoljstvo u životu (Markovina, 2019.).

Zadovoljstvo na radu je čimbenik motivacije i postignuća zaposlenika te pozitivan stav zaposlenika o radnom mjestu (Uljanić, 2015.). Motivacija se odnosi na žudnju i napor za zadovoljstvom želje ili ciljeva, a zadovoljstvo se odnosi na ispunjenje koje osjećamo zbog zadovoljenja želje. Motivacija implicira žudnju za rezultatom, dok je zadovoljstvo posljedica tog rezultata (Weihrich, Koontz, 1998.). To dovodi do zaključka da je moguće imati motivirane zaposlenike, a da pri tom nisu zadovoljni na radu i obrnuto (Buble, 2006.). Različiti motivi pokreću različite potrebe, pa se samim time i zadovoljstvo zaposlenika razlikuje i ovisi o nizu čimbenika na koje organizacije reagiraju oblikujući različite strategije, materijalne i nematerijalne (Vukajlović, Stamanović, Urošević, 2019.).

Pojedinci u organizaciji su različito motivirani jer isti čimbenici motivacije neće ostvariti jednak učinak ili uopće neće biti motivirani istim elementima. Ponekad je potrebno osigurati kombinaciju različitih čimbenika te njihovu prilagodbu promjena potrebama zaposlenika.

Da bi se utjecalo na motivaciju i zadovoljstvo zaposlenika, potrebno je permanentno analiziranje i praćenje potreba, aspiracija i preferencija ljudi, odnosno prikupljati saznanja o tome kakve nagrade zaposlenici žele za uspješan rad i radni doprinos (Brnad, Stilin, Tomljenović, 2016.).

Suvremeni uvjeti poslovanja stavljaju motivaciju i zadovoljstvo zaposlenih u fokus zanimanja menadžmenta. Izgradnjom kvalitetnog motivacijskog sustava i postizanje zadovoljstva zaposlenika radna organizacija postiže bolju produktivnost, konkurentnu sposobnost i prednost na tržištu.

Hotelijerstvo je dio turističkog gospodarstva koji kao dio turističke ponude nudi turističkom tržištu usluge smještaja, usluge pripreme i uslu- živanja prehrane i pića te pogodnosti i razne sadržaje za odmor, rekreaciju i razonodu. To sve zajedno čini hotelski proizvod koji zadovoljava turističke potrebe te potrebe gostiju za vrijeme njihovog privremenog boravka u hotelskim objektima. Obujam i kvaliteta hotelskog proizvoda ovisi o razvijenosti turističkog i ostalog gospodarstva (Benc, 2014., Cerović, 2010.). Hotel je smještajni i ugostiteljski objekt u kojem se gostima pružaju usluge smještaja i prehrane, a mogu pružati i druge ugostiteljske usluge. Zajedničko svim hotelima je da smještajne jedinice čine sobe i hotelski apartmani. U ugostiteljskom i hotelijerskom poslovanju posluživanje ima vrlo veliku ulogu u procesu zadovoljenja potreba i želja gostiju raznovrsnom hranom, pićem i željenim napicima. Da bi posluživanje bilo stručno, kvalitetno, kulturno, pravovremeno i ekonomično obavljeno u svim fazama i na zadovoljstvo gostiju, potrebno je imati stručno osoblje dobre tjelesne kondicije, ljubazno, veselo, nasmijano i uslužno, te psihički zdravo. Kultura rada, odnosno kultura pripremanja i pružanja usluga uključuje obrazovanje, etički aspekt, estetiku, kulturu komuniciranja, higijenu i zaštitu na radu.

S druge strane zaposlenicima u hotelijerstvu potrebno je preventivnim mjerama očuvati zdravlje, radnu sposobnost i optimalnu učinkovitost. Radnici u hotelijerstvu prilikom obavljanja rada izloženi su različitim opasnostima, štetnostima i naporima, pri čemu posao pretežno obavljaju stojeći što nepovoljno utječe na mišićno-koštani sustav. Najčešće ozljede nastaju zbog nepravilnog rukovanja radnom opremom, klizavog ili neravnog poda, psihofizičkog napora, dodira s vrućim i hladnim predmetima i dr. (Jurjević, 2019.).

\section{METODOLOGIJA ISPITIVANJA}

\section{Ispitanici}

$\mathrm{U}$ ispitivanju su sudjelovala 84 radnika koji obavljaju sljedeće poslove:

- radno mjesto I-servir obavlja poslove postavIjanja i raspremanja stola, odlaganje čistog i prljavog posuđa, ručno i strojno pranje posuđa, te posluživanje gostiju (slika 1a),

- radno mjesto II-konobar obavlja poslove posluživanja hrane i pića, komunikaciju s oso- 
bljem kuhinje i šanka, posluživanja gostiju, vodi brigu o čistoći opreme i dr. (slika 1a),

- radno mjesto III-pomoćni kuhar obavlja poslove pripreme namirnica, poslove čišćenja i pranja, sudjeluje u izdavanju hrane, ručno i strojno pere posuđe, slaže posuđe i dr. (slika 1b),

- radno mjesto IV-kuhar obavlja poslove pripreme toplih i hladnih jela, sastavljanja jelovnika, pripreme za posluživanje jela i dr. (slika 1b).

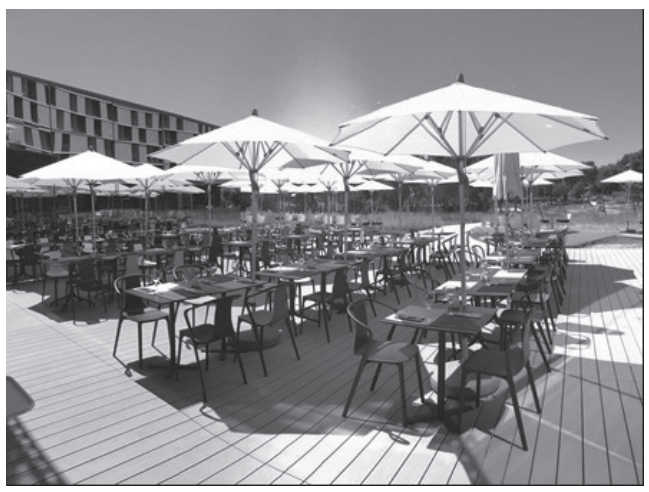

a - radno mjesto servir i konobar

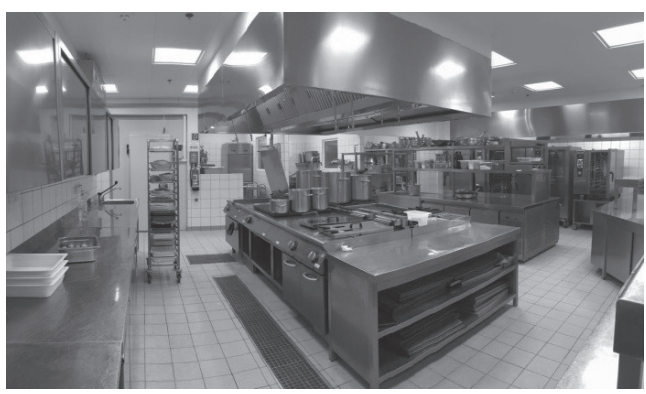

b - radno mjesto pomoćni kuhar i kuhar

Slika 1. Radna mjesta anketiranih zaposlenika

Figure 1. Work places covered in the questionnaire

$U$ hotelu su ispitana anketnim upitnikom 88 zaposlenika na četiri radna mjesta (servir - 22 zaposlenika, konobar - 22 zaposlenika, pomoćni kuhar - 22 zaposlenika, kuhar - 22 zaposlenika).

\section{Instrument za prikupljanje podataka}

Anketni upitnik je pismeno prikupljanje podataka o stavovima i mišljenja na reprezentativnom uzorku ispitanika. Putem anketnog upitnika može se doći do podataka o doživljaju (stavovi, mišljenje) zaposlenika. Anketni upitnik je zatvorenog tipa, pri čemu su zaposlenicima ponuđeni odgovori (Brajdić, 2002.).

Anketnim upitnikom obuhvaćena su osnovna pitanja (spol, dob) te jasnoća rada, konzistentnost, kompatibilnost, informiranost, funkcionalnost, fleksibilnost i kontrola, prevencija i ispravljanje grešaka, upute za siguran rad i sigurnost, funkcioniranje sustava, zadovoljstvo plaćom i radnim vremenom (Tablica 1).

\section{Postupak}

Upitnik je podijeljen pojedinim zaposlenicima koji su ga samostalno ispunili anonimno, što daje veću vjerojatnost pouzdanih odgovora. Pitanja su jednostavna, direktna i razumljiva, pri čemu zaposlenici odgovaraju zaokruživanjem odgovora DA ili NE.

Cilj ispitivanja je utvrditi psihosocijalne čimbenike na radnom mjestu i zadovoljstvo radnika u hotelijerstvu.

Rezultati dobiveni anketnim upitnikom obrađeni su u programu Microsoft Exel, te grafički prikazani.

\section{REZULTATI}

Na poslovima servir, pomoćni kuhar i kuhar radi većinom ženska radna populacija, dok je na poslovima konobar većim dijelom zastupljena muška populacija (slika 2).

Starosna dob zaposlenika kreće se u rasponu od 16 do 46 i više godina. Većinski dio zaposlenika na radnom mjestu servir kreće se u rasponu od 16 do 25 godina, a na radnom mjestu konobar kreće se između 16 i 25 godina. Na radnom mjestu pomoćni kuhar većinski dio zaposlenih je u dobnoj skupini 16-20 godina, te 26-31 godine, dok je u ostalim skupinama manje zaposlenih. Najveći dio zaposlene populacije na radnom mjestu kuhar kreće se u rasponu od 32 do 45 godina (slika 3). 


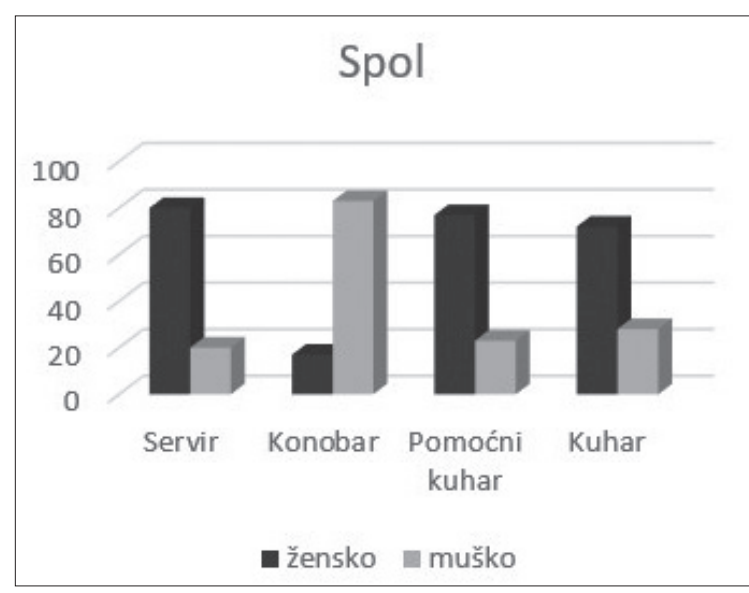

Slika 2. Anketirani zaposlenici s obzirom na spol Figure 2. Employees' sex

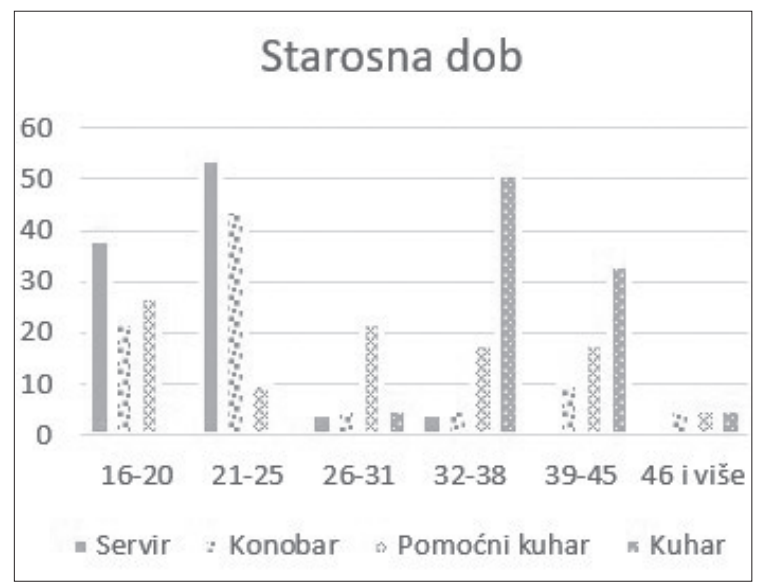

Slika 3. Anketirani zaposlenici prema starosnoj dobi

Figure 3. Employees' ages

U sklopu pitanja jasnoće posla zaposlenicima su postavljena dva pitanja u vezi s upućenosti na posao i zadovoljstvom organizacijom rada. Zaposlenici su zadovoljni s upućenosti u posao (servir $77 \%$; konobar $100 \%$; pomoćni kuhar $77 \%$; kuhar $100 \%$ ), kao i organizacijom posla (servir $90 \%$; konobar 96 \%; pomoćni kuhar 77 \%; kuhar 100 $\%)$; (slika 4).

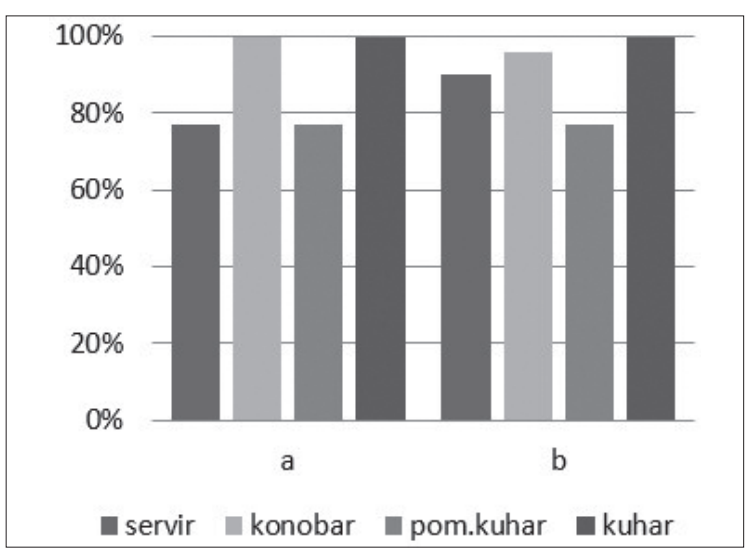

Slika 4. Rezultati anketiranih zaposlenika s obzirom na jasnoću posla

Figure 4. Perceived clarity of work duties

Na pitanja u vezi s konzistentnosti radne organizacije (odgovornost) postavljena su tri pitanja (dosljednost posla, odnos nadređenih, promjena načina rada). Po pojedinim radnim mjestima za dosljednost posla zaposlenici su odgovorili pozitivno (77-87 \%), odnos nadređenih prema zaposlenicima su odgovorili pozitivno (90-100 \%), te o posljedicama promjene posla (87-100 \%); (slika 5).

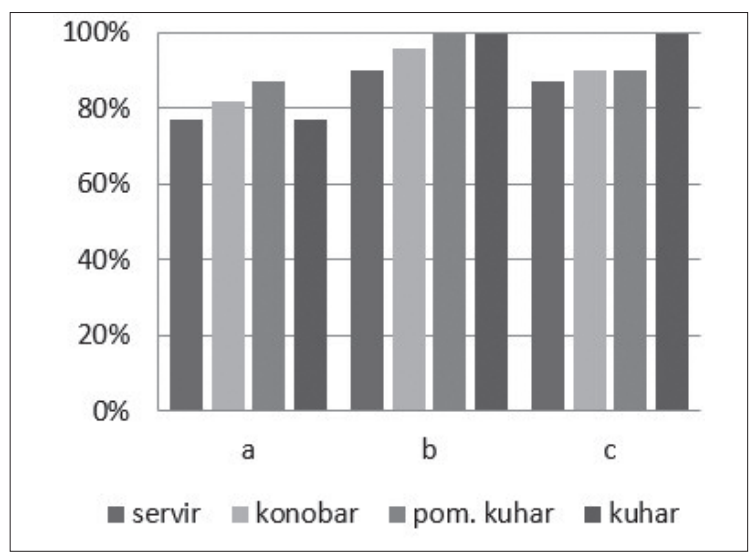

Slika 5. Rezultati anketiranih zaposlenika s obzirom na konzistentnost

Figure 5. Consistency 
Na pitanje o kompatibilnosti posla radnici su pozitivno odgovorili (82-87\%), (slika 6), te o pitanju informiranosti o svojem poslu (87-100 $\%$ ); (slika 7).

Na pitanje jesu li zaposlenicima osigurani povoljni radni uvjeti s obzirom na sredstva za rad zaposlenici su odgovorili pozitivno (96-100 $\%)$; (slika 8).

S obzirom na fleksibilnost poslodavca prema potrebama zaposlenika (slobodni dani, smjene i dr.), radnici su odgovorili pozitivno u rasponu

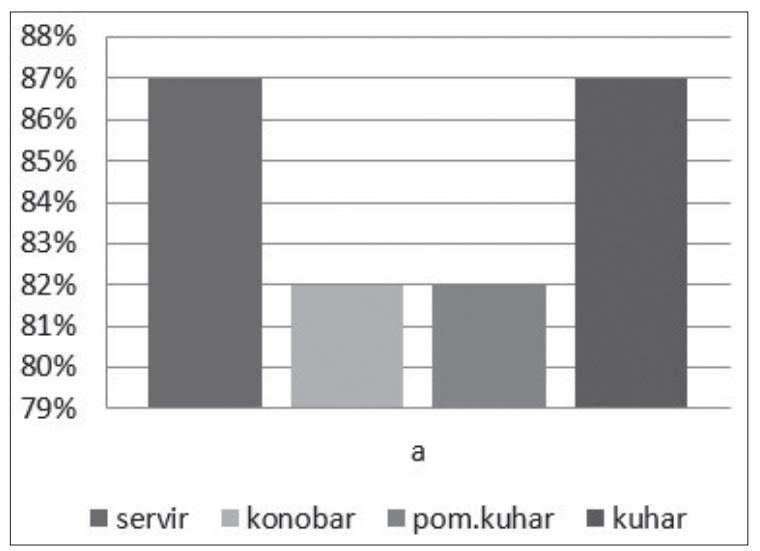

Slika 6. Rezultati anketiranih zaposlenika s obzirom na kompatibilnost

Figure 6. Compatibility

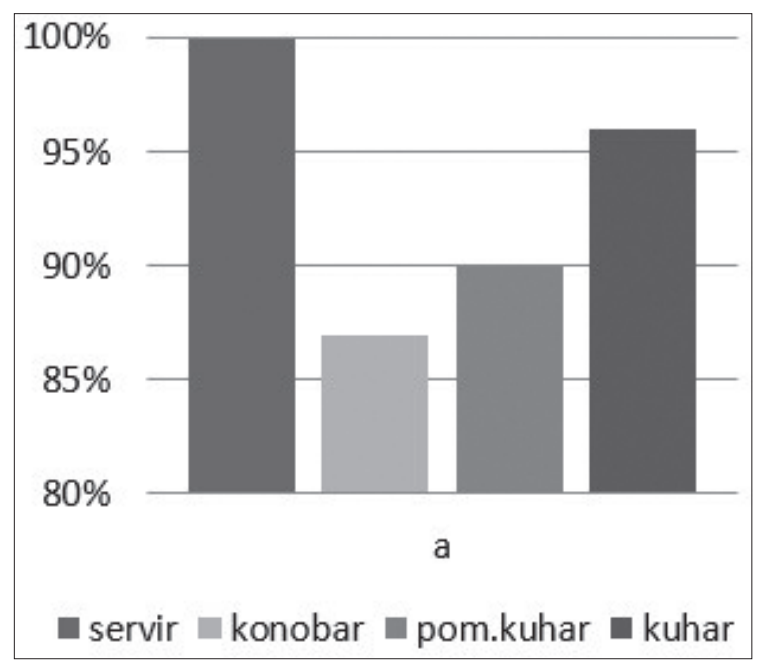

Slika 7. Rezultati anketiranih zaposlenika s obzirom na informiranost

Figure 7. Degree of received job information od 90 do $100 \%$ ovisno o radnom mjestu, dok na pitanje kontroliraju li nadređeni rad zaposlenika odgovorili su između 82 i 90 \% (slika 9).

U sklopu prevencije i ispravljanja grešaka radnicima su postavljena dva pitanja, pri čemu radnici smatraju da nema pogrešaka u radu (14-22\%), te da nema pogrešaka u organizaciji rada (18-27\%); (slika 10). Na pitanje u vezi s uputama za siguran rad zaposlenici su zadovoljni i ocijenili su pozitivno (100\%), te da su informacije na dostupnim mjestima (100\%); (slika 11).

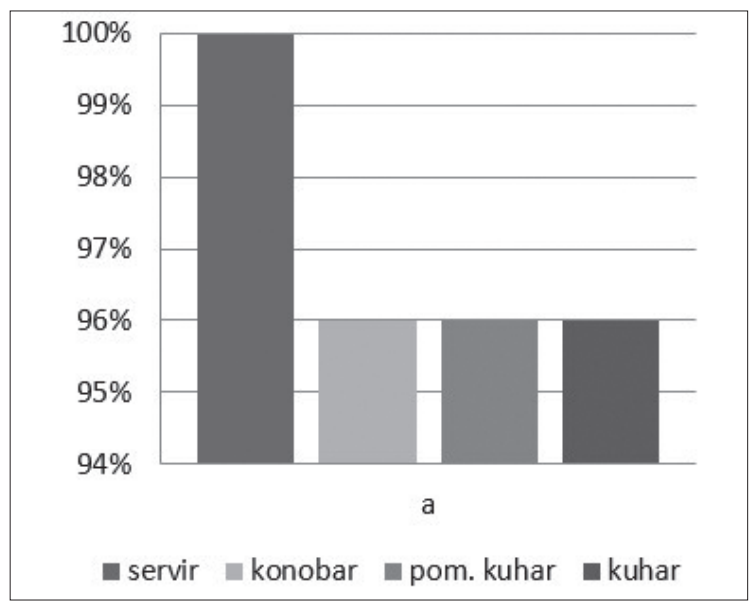

Slika 8. Rezultati anketiranih zaposlenika s obzirom na funkcionalnost

Figure 8. Funcionality

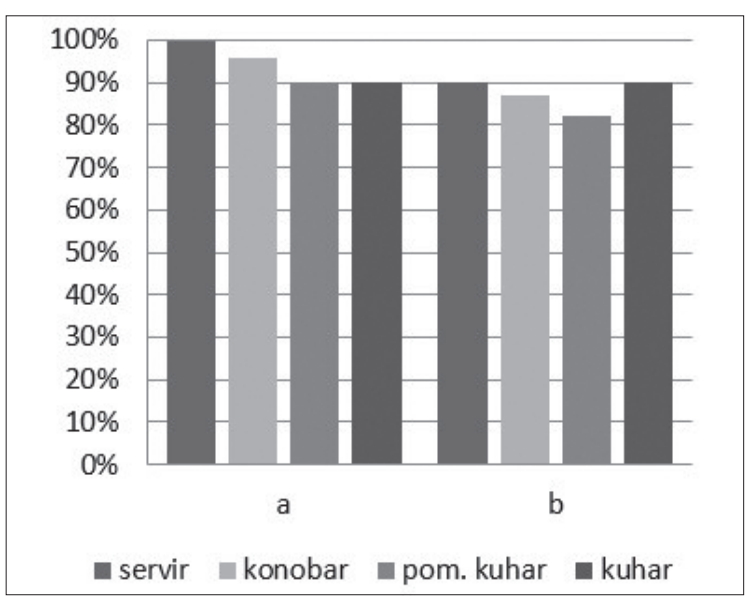

Slika 9. Rezultati anketiranih zaposlenika s obzirom na fleksibilnost i kontrolu

Figure 9. Flexibility and control 


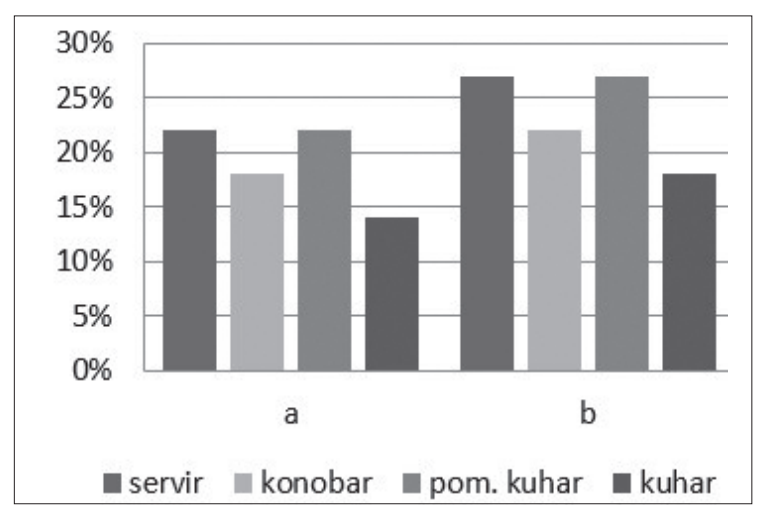

Slika 10. Rezultati anketiranja zaposlenika s obzirom na prevenciju i ispravljanje grešaka

Figure 10. Fault prevention and correction

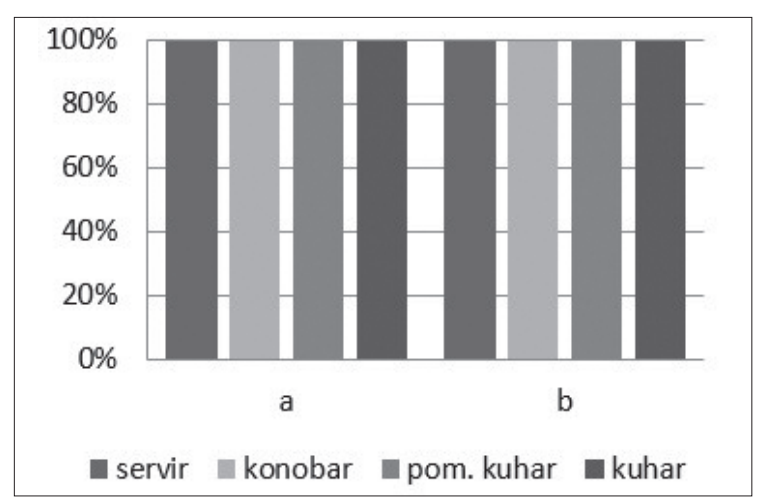

Slika 11. Rezultati anketiranja zaposlenika s obzirom na upute za siguran rad

Figure 11. Satisfaction with respect to the instructions for safe work

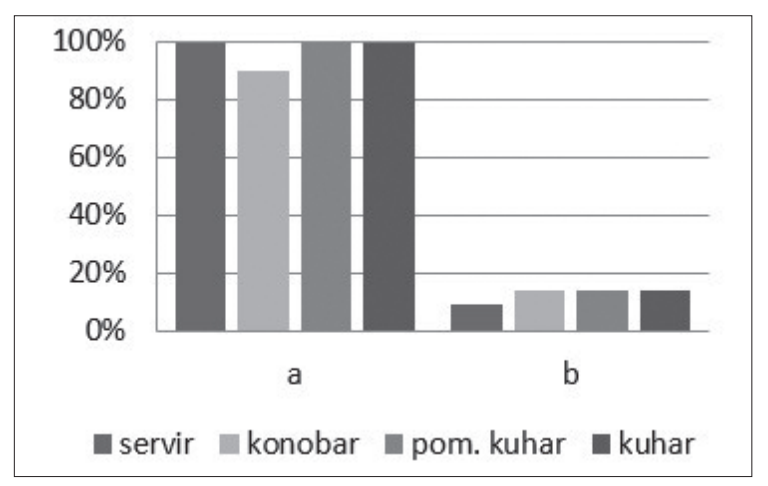

Slika 12. Rezultati anketiranja zaposlenika s obzirom na sigurnost

Figure 12. Safety in the unit

Radnici se osjećaju sigurno na radnom mjestu (90-100\%), te ništa ne ugrožava njihovu sigurnost (9-14\%); (slika 12). Na pitanje

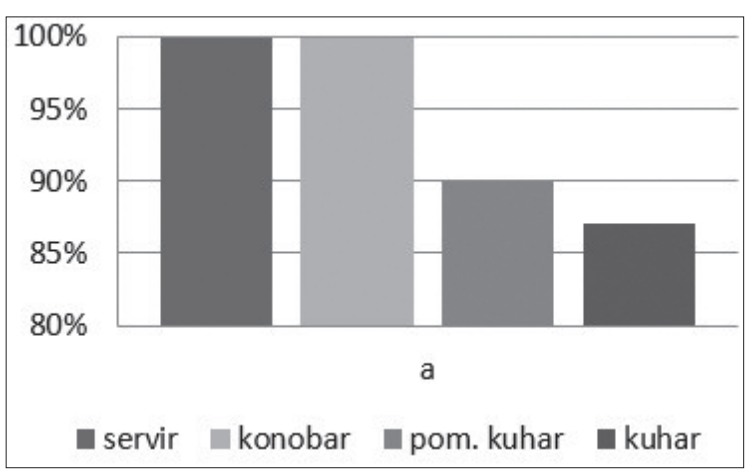

Slika 13. Rezultati anketiranja zaposlenika s obzirom na funkcioniranje sustava

Figure 13. System functioning

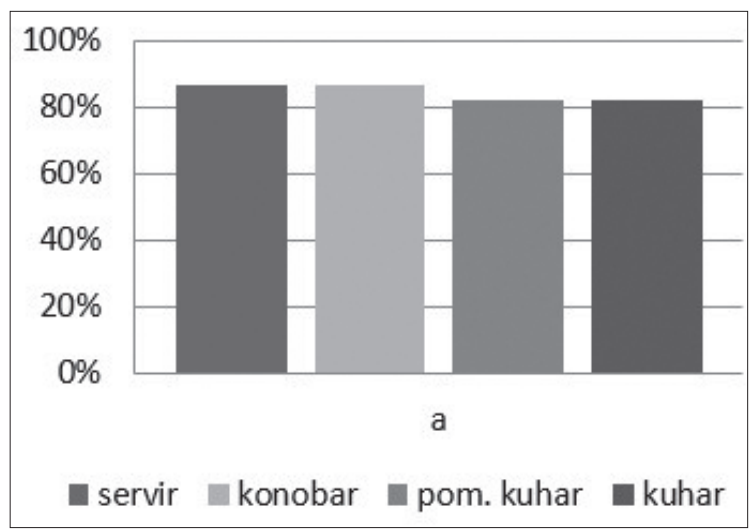

Slika 14. Rezultati anketiranja zaposlenika s obzirom na zadovoljstvo plaćom

Figure 14. Pay satisfaction

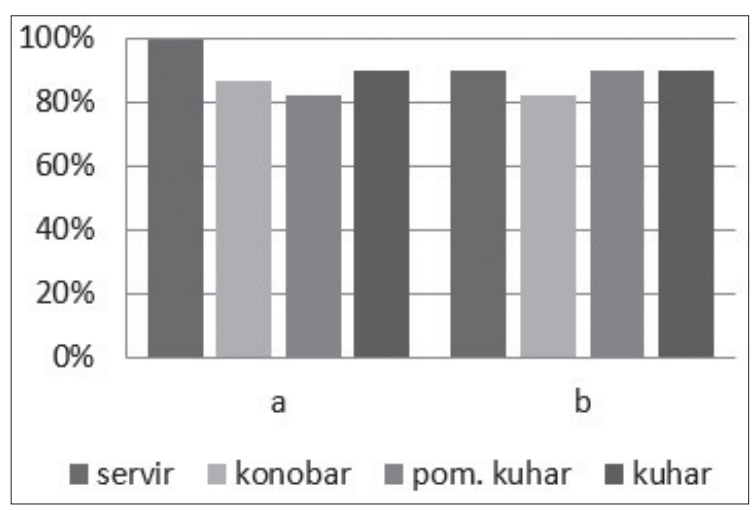

Slika 15. Rezultati anketiranja zaposlenika s obzirom na zadovoljstvo radnim vremenom

Figure 15. Satisfaction with working hours

jesu li zadovoljni na svojem radnom mjestu zaposlenici su odgovorili u rasponu 87-100\% (slika 13). 
Na pitanje u vezi sa zadovoljstvom plaćom zaposlenici su odgovorili u rasponu $82-87 \%$, ovisno o radnom mjestu (slika 14). U sklopu skupine pitanja u vezi sa zadovoljstvom radnim vremenom odgovorili su u rasponu 82-100 \% , dok o dovoljno slobodnom vremenu u rasponu $82-90 \%$.

\section{RASPRAVA}

Psihosocijalni čimbenici su elementi koji potencijalno utječu na psihološke odgovore zaposlenika na rad i radne uvjete i uključuju način rada (radove, radno okruženje, metode) i kontekst u kojem se obavlja rad (uključujući odnose i interakciju s upraviteljem i nadređenima, kolegama i suradnicima).

$\mathrm{U}$ jednom hotelu su anketnim upitnikom ispitana 84 radnika na četiri različita radna mjesta. Upitnik ima 14 odjeljaka s ukupno 23 pitanja na koje su radnici odgovarali s DA ili NE.

$\mathrm{Na}$ temelju provedenog anketiranja vidljivo je da poslodavac vodi računa o osposobljenosti zaposlenika i organizaciji podjele rada po pojedinim radnim mjestima. Za odgovornost radne organizacije (dosljednost posla, odnos nadređenih, promjena načina rada) zaposleni su odgovorili pozitivno što govori da poslodavac vodi računa o svojim zaposlenicima, te da je posao dobro organiziran. Zaposlenici su zadovoljni svojim poslom i imaju jasne informacije o svojem radu, što znači da poslodavac uvažava rad zaposlenika i vodi računa o njegovom zadovoljstvu na radu. Nadalje, zaposlenici su zadovoljni uvjetima rada na radnom mjestu, te je poslodavac fleksibilan prema njihovim potrebama s obzirom na slobodne dane i smjene. U radnoj organizaciji zaposlenici su zadovoljni organizacijom posla, dok je udio pogrešaka minimalan. Poslodavac vodi računa o sigurnosti zaposlenika na radnom mjestu, te ga o tome dodatno educira i osposobljava, tako da se osjećaju sigurno i zadovoljno. Zaposlenici su u visokom postotku (87-100 \%) zadovoljni na svojem radnom mjestu, dok su ovisno o radnom mjestu različito zadovoljni plaćom (82-100 \%). Također, ovisno o radnom mjestu zaposlenici su različito zadovoljni radnim vremenom (82-100 \%), te slobodnim vremenom (82-90 \%).
Nakon provedenog anketiranja na radnom mjestu servir, konobar, pomoćni kuhar i kuhar može se zaključiti da su zaposlenici zadovoljni radnom organizacijom o pitanju organiziranosti, funkcioniranja sustava, sigurnosti na radu, dok bi bila potrebna poboljšanja o pitanju radnog vremena, plaća i slobodnog vremena.

Vidljivo je da poslodavac vodi računa o uvjetima rada zaposlenika, njihovom zadovoljstvu na radu, organizaciji posla te ne ograničava mogućnost socijalne interakcije, pri čemu je uspostavljena dobra komunikacija s nadređenima i/ili kolegama. Kako je važno poštovati pravo na siguran i zdrav radni okoliš, na svim razinama zaposlenici aktivno sudjeluju u osiguranju sigurnog i zdravog okoliša na osnovi definiranih prava, odgovornosti i dužnosti.

U svakom sustavu moguća su određena poboljšanja što ovaj anketni upitnik pokazuje i daje mogućnost da određene segmente poslodavac poboljša. S druge strane, uvijek postoji određeni broj nezadovoljnih zaposlenika, što ovisi o individualnim stavovima o radu te percipiranju određene situacije.

\section{ZAKLJUČAK}

Zadovoljni zaposlenici postižu višu radnu uspješnost, a time raste i ukupna uspješnost organizacije, te njezina konkurentnost na tržištu. Težnja organizacije mora biti da zadovolji potrebe i želje većeg broja zaposlenika, te da je usmjerena na podizanje individualne radne uspješnosti, stvarajući i nagrađujući poželjne oblike ponašanja (Brnad, Stilin, Tomljenović, 2016.).

U provedenom anketnom upitniku na 88 zaposlenika utvrđeno je da su zaposlenici zadovoljni radnom organizacijom o pitanju organiziranosti, funkcioniranja sustava, sigurnosti na radu, dok bi bila potrebna poboljšanja o pitanju radnog vremena, plaća i slobodnog vremena.

S obzirom da su ljudske potrebe različite i razlikuju se ne samo od čovjeka do čovjeka nego i kod samog pojedinca su promjenjive prirode, nije moguće očekivati $100 \%$ zadovoljstvo s radom na pojedinim radnim mjestima. 


\section{PRILOG}

Tablica 1. Prikaz anketnog upitnika

Table 1. The survey questionnaire

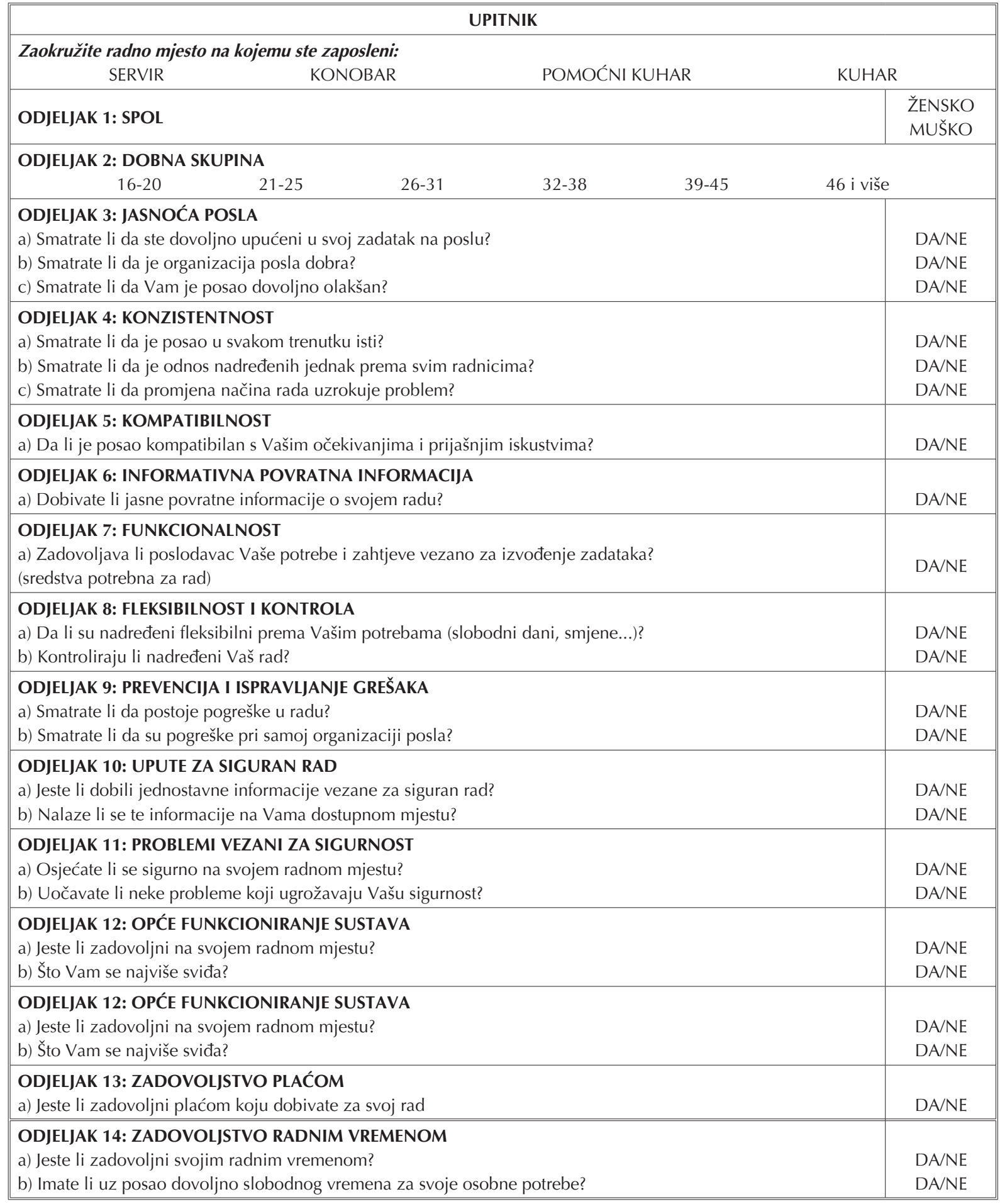




\section{LITERATURA}

Bene, R. B.: Marketing u hotelijerstvu, 2 izmijenjeno i dopunjeno izdanje, udžbenik Fakulteta za turistički i hotelski menadžment, Opatija, 2004.

Brajdić, I.: Vrednovanje anketnih upitnika sa stajališta ispitanika-menadžera u turizmu, Tour. hosp.mang., 8, 2012., 1-2, 65-78.

Brnad, A., Stilin, A., Tomljenović, Lj.: Istraživanje motivacije i zadovoljstva zaposlenika u Republici Hrvatskoj, Zbornik Veleučilišta u Rijeci, 4, 2016., 1, 109-122.

Cerović, Z.: Hotelski menadžment, 2 izmijenjeno izdanje, udžbenik Sveučilišta u Rijeci Fakulteta za menadžment u turizmu i ugostiteljstvu, Rijeka, 2010.

International Labour Office (ILO) and joint WHO Committee on Occupational Health, 1986., Psychosocial factors at work: Recognition and control, Occupational Safety and Health Series no. 56, December, ILO, Geneva, 81

Jurjević, D.: Sigurnost na radu za radnike u ugostiteljstvu, dostupno na: www.scri.uniri. hr>files>dokumenti_scri, pristupljeno: 7.1.2019.
Markovina, J.: Zadovoljstvo poslom i odanost organizaciji-primjer Agronomskog fakulteta Zagreb, dostupno na: sa.agr.hr>pdf>sa2013_p0217, pristupljeno: 3.1.2019.

Noe, R.A., Hollenbeck, J.R., Gerhart, B., Wright, P.M.: Menadžment ljudskih potencijala, 3. izdanje, Mate d.o.o., , Zagreb, 2006.

Pupovac, D., Lipovača, S., Sečen, V.: Zadovoljstvo zaposlenika-čimbenik uspješnosti suvremenih poduzeća, dostupno na: httpp//hrčak.srce.hr.file, pristupljeno: 3.1.2019.

Uljanić, L.: Povezanost zadovoljstva zaposlenika i upravljanje odnosima s korisnicima, diplomski rad, Sveučilište Jurja Dobrile u Puli, Fakultet ekonomije i turizma "Dr. Mijo Mirković", Pula, 2015.

Vukajlović, Đ., Stamanović, M., Urošević, S.: Analiza o zadovoljstvu i motivaciji zaposlenih materijalnih $i$ nematrijalnih motivacionim čimbenicima, dostupno na: httpp//hrčak.srce. hr.file/1192337, pristupljeno: 3.1.2019.

Weihrich, H., Koontz, H.: Menadžment, Mate d.o.o., Zagreb, 1998.

Zaštita na radu u ugostiteljstvu, dostupno na www.zastitanaradu.com.hr>novosti, pristupljeno: 3.1.2019. 


\section{EMPLOYEE SATISFACTION SURVEY IN} HOTEL INDUSTRY

SUMMARY: Job satisfaction is a set of positive or negative feelings employees experience in their work, and they relate to various factors: co-workers, job description, superiors, pay, working conditions, hours, promotion, acknowledgement, status, success, responsibility, safety, possibility for further development and other. Employee satisfaction was investigated using the closeended survey questionnaire method and it included the following employees of a hotel: server, waiter, sous-chef and chef. The survey questionnaire consisted of 14 parts and a total of 24 questions, including both general questions and those directly affecting the employees' satisfaction at work (pay, hours, safety at work, work place, organisation, awareness and other). The analysis of the answers showed that the employees are satisfied with the work place on all counts, with the employee satisfaction percentage ranging from $77 \%$ to $100 \%$, depending on the question.

Key words: hotel industry, satisfaction at work, survey questionnaire

Original scientific paper Received: 2019-01-21

Accepted: 2019-10-02 